\title{
A delação premiada no combate ao crime organizado ${ }^{1}$
}

Fabiana Greghi ${ }^{2}$

\section{Resumo}

\begin{abstract}
Devido à complexidade e ao caráter multiforme do crime organizado, os instrumentos processuais tradicionais utilizados para a apuração da criminalidade individualizada são inócuos para o seu tratamento. Neste contexto é que surge o fio condutor do presente artigo, qual seja, a demonstração da delação premiada como aparato apto ao combate à criminalidade organizada. $O$ instituto premial, de evidente notoriedade nos dias atuais, é um intrigante tema a ser abordado, já que, embora não seja produto de criação recente no ordenamento jurídico brasileiro, ainda assim, o legislador pátrio não se atentou em delinear sua incidência de forma satisfatória, nem tão pouco zelou por uma regulamentação normativa isenta de falhas e obscuridades. A relevância da problemática a ser exposta dá-se em razão da delação premiada estar intrinsecamente atrelada à política criminal, buscando dar efetividade ao sistema penal na repressão à estrutura cada vez mais desafiante da delinqüência organizada. Urge, assim, adequá-la à realidade da criminalidade brasileira, ante os extraordinários benefícios que podem dela advir, desde que aplicada com a lucidez necessária, de forma a viabilizar a eficiência do Direito Penal no embate contra organizações criminosas.
\end{abstract}

Palavras-Chave: Delação premiada; Combate; Crime organizado.

\section{Introdução}

No que diz respeito à criminalidade, o maior desafio contemporâneo concentra-se em alcançar maneiras eficazes de reprimir o crime organizado.

Não obstante, a atual realidade social marcada pelos avanços tecnológicos possibilitar uma melhor qualidade de vida, suscita também novas formas delituosas organizadas que apostam na impunidade para aniquilar a ordem e a segurança pública, maculando desta forma o Estado Democrático de Direito.

Vivemos numa sociedade sinalizada pela globalização, que ao mesmo tempo em que oferece subsídios para um intenso fluxo econômico, político, social e cultural, recrudesce o fenômeno da criminalidade organizada.

1 Este artigo teve por referência o Trabalho de Conclusão de Curso apresentado ao Curso de Direito da Universidade Estadual de Londrina, sob orientação da Profa Msa Rossana Helena Karatzios e aprovado com nota 10.0

2 Acadêmica do 5o ano matutino do curso de Direito da Universidade Estadual de Londrina. E-mail: fabianagreghi@hotmail.com. 
Com a globalização a análise da delinqüência muda de foco: os delitos do paradigma clássico do processo de criminalização perdem espaço para os delitos classificados criminologicamente como crimes of the powerful.

Estes crimes caracterizam-se pelo portentoso grau de ofensividade à paz pública, merecendo pois um tratamento penal e processual penal diferenciado do dispensado à criminalidade comum. Mesmo porque, a criminalidade organizada escarnece dos instrumentos processuais tradicionais utilizados para a apuração da delinqüência individualizada, que se mostram defasados ante o seu caráter multiforme. $\mathrm{E}$ de outro modo não poderia ser, já que é ilógico tentar combater coisas distintas valendo-se de um único método, ou seja, é irracional a aplicação de um mesmo aparato para a contenção de criminalidades abissalmente diversas.

Neste contexto é que emerge o enfoque do presente artigo, qual seja, a demonstração da delação premiada como meio hábil à repressão do crime organizado.

Ela, como se verá, caso seja aplicada com a devida cautela que reclama, constitui um arsenal poderoso para desestabilizar a estrutura cada vez mais desafiante do crime organizado e dar efetividade ao sistema penal na medida em que minimiza a transgressão aos dispositivos penais e impede que a impunidade se alastre.

O método utilizado neste artigo desde a fase investigativa até à fase expositiva é o dedutivo. Isso significa dizer que a construção do saber jurídico aqui pretendida dá-se pela extração discursiva do conhecimento a partir de premissas gerais aplicáveis a hipóteses concretas, ou seja, parte-se do geral para o particular.

Não se pretende aqui esgotar de forma alguma a temática. Muito pelo contrário. Objetiva-se com o auxílio dos pontos de vista de renomados estudiosos, fomentar ainda mais a discussão acerca do intrigante e complexo tema a ser abordado.

\section{0 fenômeno da criminalidade organizada}

Antes de adentrar na temática a que este artigo se propõe, salutar é fazer breves considerações acerca do fenômeno da criminalidade organizada. Para tanto, imprescindível que se perquira as características peculiares do crime organizado que justificam o emprego da delação premiada. 
De acordo com os romanos, initium doctrinae sit consideratio nominis, isto é, a doutrina deve iniciar o estudo de determinado assunto pelo nome. Portanto, de extrema relevância é a conceituação do crime organizado, uma vez que a aplicação da delação premiada, protagonista deste artigo, visa ao seu combate.

O legislador brasileiro omitiu-se e deixou a árdua tarefa da definição do crime organizado a cargo da doutrina e da jurisprudência.

Perdeu-se a oportunidade de delimitar o que seja crime organizado com a edição da Lei 9.034/1995 e sua posterior alteração pela Lei 10.217/2001. Até hoje o ordenamento jurídico brasileiro encontra-se desprovido de qualquer contorno ou alusão ao conteúdo da criminalidade organizada. No dizer de Luiz Flávio Gomes, "continuamos legislativamente sem saber o que é que devemos entender por crime organizado (strictu senso), dentro da extensa realidade fenomenológica criminal". (GOMES; CERVINI, 1997, p. 89)

Diante do déficit conceitual cultivado pelo legislador, não restou outra alternativa a não ser o estudo cada vez mais apurado na busca de se revelar o perfil do crime organizado, haja vista a impossibilidade de reprimir eficientemente o que se desconhece.

Feitas essas ponderações, para que se possa entender a estrutura do crime organizado, passa-se a buscar a caracterização das organizações criminosas disseminada pela doutrina, em virtude da carência de uma definição legal clara e precisa a respeito do fenômeno criminal em estudo.

Passa-se agora a tratar dos dados elementares caracterizadores das organizações criminosas que acima foram descritos.

Uma das mais notáveis características das organizações criminosas é a estrutura hierárquico-piramidal que possuem. Arquiteturam-se como se fossem verdadeiras empresas obstinadas a acompanharem as leis do mercado, oferecendo o que é ilícito para promoverem atividades proibidas, obtendo, assim, lucros fabulosos.

Nota constitutiva desse vínculo hierárquico é a impessoalidade da organização, que inclusive a aproxima de uma sociedade anônima. Não se externa a composição das organizações, muito pelo contrário, o conteúdo e o seu funcionamento só são sabidos internamente. Isso acaba por dificultar e muito a obtenção de provas e o desmantelamento da organização, mesmo porque, geralmente os membros que são alcançados estão na base 
da pirâmide e são, depois de capturados, facilmente substituídos por outros, não abalando, de modo algum, as associações criminosas organizadas.

Outro ponto característico é a divisão de tarefas entre os componentes das organizações criminosas.

Raúl Cervini, em primoroso estudo, salienta que as organizações criminosas constituem-se de coordenação, consistente na unidade de decisão operativa, estabelecendo-se uma relação de subordinação e ajuda mútua entre os diferentes segmentos que integram o grupo criminoso. Ao mesmo tempo em que existe uma divisão de trabalho, há em jogo uma comunhão de interesses, com a interdependência entre seus membros para obterem a maior receita possível com a realização dos crimes. (CERVINI; GOMES, 1997, p. 221).

Cada indivíduo tem sua tarefa previamente definida, de forma a especializar a prestação de serviços e elevar a sua eficácia.

Em suma, numa associação criminosa há uma equipe voltada para as atividades ilícitas que detém uma hierarquia própria e capaz de um planejamento empresarial, o qual tem como viga mestra a divisão de trabalho.

Característica saliente e que até mesmo é condição de manutenção das organizações criminosas é a restrição de seus membros. Não é qualquer pessoa que pode ser aceita para compor os quadros das associações criminosas. Deve-se ter cuidado na seleção dos seus membros para obstar a admissão de pessoas despreparadas, ou pior, a convocação de agentes da polícia que se infiltram nas organizações para desbaratá-las.

As organizações criminosas também ostentam elevado poder de corrupção. Os agentes públicos, corrompidos pelo crime, ou participam efetivamente das atividades criminosas, ou viabilizam a execução delas, acobertando os demais criminosos para que não sejam desmascarados pela lei penal.

Como bem enfatizou Hassemer (1994, p. 63), a criminalidade organizada:

Não é apenas uma organização bem feita, não é somente uma organização internacional, mas é, em última análise, a corrupção da Legislatura, da Magistratura, do Ministério Público, da Polícia, ou seja, a paralisação estatal no combate à criminalidade [...]. 
As organizações criminosas existem preponderantemente para a obtenção de lucros fáceis. Raramente ter-se-á uma organização sem fim empresarial ou econômico, já que a criminalidade organizada se orienta em busca de renda e de poder. Óbvio que podem existir interesses políticos ou religiosos, ou outros que venham norteá-la.

Segundo a pesquisa de Eduardo Araujo da Silva, estima-se que o mercado envolvendo todas as espécies de delinqüência organizada seja responsável por mais de $1 / 4$ (um quarto) do dinheiro em circulação em todo o mundo. Matéria publicada nos jornais The Los Angeles Times e no Estado de S. Paulo mostrou que as organizações transnacionais movimentam anualmente cerca de US\$ 850 bilhões. Ainda, segundo a Organização das Nações Unidas, só a renda obtida pelo tráfico de entorpecentes (cerca de US\$ 400 milhões) corresponde a $8 \%$ da renda do comércio internacional. (apud SILVA, 2003, p. 28).

Outro traço peculiar é o domínio territorial. Uma organização criminosa para estar bem sedimentada em um território precisa ter o domínio sobre ele. Claro que na medida em que cresça, poderá desbravar outros espaços, tanto os neutros quanto os já dominados por outra organização. Nessa última hipótese, provavelmente haverá o desencadeamento de um conflito, afinal, cada organização zela por sua soberania e não permite que outra se imiscua em sua zona de atuação.

As associações criminosas organizadas, via de regra, também apresentam uma considerável sofisticação nos seus meios operacionais. Utilizam-se de meios informáticos e de telecomunicação que nem mesmo o Estado detém, e sobre os quais, às vezes até desconhece a existência.

O desenvolvimento tecnológico conquistado pelas organizações visa impedir a colheita de provas, uma vez que o Estado, desmuniciado de toda essa tecnologia, fica longe de ter êxito em uma persecução penal.

$\mathrm{O}$ alto poder de intimidação é outro fator que merece ser considerado. A "lei do silêncio" (denominada pelos italianos de omertà) é imposta aos integrantes das organizações, bem como a pessoas estranhas a elas, sendo mantida por meio das mais desumanas e violentas artimanhas contra aqueles que desafiam desrespeitá-las ou contra seus familiares, com a intenção de intimidar o testemunho, a delação e outras atitudes que possam culminar no desmanche das organizações. 
Outra das características do crime organizado, notadamente presente nos dias atuais, é a sua internacionalização. Isso decorre do fato de os criminosos, na seara internacional, não se defrontarem com impedimentos para se integrarem, principalmente depois do processo de globalização que facilitou a comunicação a grandes distâncias, ocasionando o envolvimento de diversas organizações com outras de regiões diferentes..

Cumpre destacar que as características aqui atribuídas às organizações criminosas são meramente exemplificativas, dado o caráter cambiante das mesmas. Convém frisar ainda que não é preciso estarem esses atributos cumulativamente presentes para que se tenha a existência de uma associação ilícita organizada. Cada caso tem suas peculiaridades.

Pois bem, diante dos atributos ínsitos ao crime organizado aqui tratados que o diferenciam da criminalidade de massa, urge a adoção de estratégias diferenciadas para que ele possa ser satisfatoriamente combatido.

Neste contexto é que surge a delação premiada como mecanismo jurídico eficaz na repressão da criminalidade organizada, já que não se pode reprimir crimes notadamente diversos com os mesmo instrumentos jurídicos.

\section{A delação premiada e o combate ao crime organizado}

\subsection{Conceito, natureza jurídica e a classificação da delação premiada}

Restou demonstrada ao longo do capítulo anterior, ainda que de forma singela, a indispensabilidade da adoção de um tratamento diferenciado para a derruição do crime organizado. Desta constatação é que a delação premiada avulta-se como poderoso instrumento para desempenhar tal propósito.

O que se quer é viabilizar o combate ao crime organizado, dando efetividade ao sistema penal para capacitá-lo à mantença da ordem e da segurança pública. Uma maneira louvável de se alcançar essa pretensão é justamente por meio da delação premiada. Em abono a essa assertiva apresenta-se o secular ensinamento de Rudolf Von Ihering, que, pressentindo a força do crime organizado e a debilidade dos Estados Nacionais em contê-lo nos séculos vindouros, apontou o direito premial como solução:

Um dia, os juristas vão se ocupar do direito premial. E farão isso quando, pressionados pelas necessidades práticas, conseguirem introduzir matéria premial 
dentro do direito, isto é, fora da mera faculdade ou arbítrio. Delimitando-o com regras precisas, nem tanto no interesse do aspirante ao prêmio, mas, sobretudo no interesse superior da coletividade (apud CERQUEIRA, 2005, p. 25).

Por ora analisar-se-á a conceituação, a natureza jurídica e a sua classificação, para depois esmiuçar o seu conteúdo.

O termo delação advém do latim delatione e significa "denunciar, revelar (crime ou delito); acusar como autor de crime ou delito; deixar perceber; denunciar como culpado; denunciar-se como culpado; acusar-se". (FERREIRA, 1999, p. 617).

Premiar, por seu turno, é "dar prêmio ou galardão a; laurear; galardoar; pagar; recompensar; remunerar". (FERREIRA, 1999, p. 629).

Daí se apura que a delação premiada é a "incriminação de terceiro, realizada por um suspeito, indiciado ou réu, no bojo de seu interrogatório (ou em outro ato)." (JESUS, 2006, p. 9) Diz-se premiada por ser "incentivada pelo legislador, que premia o delator, concedendo-Ihe benefícios (redução da pena, perdão judicial, aplicação de regime penitenciário brando, etc.)". (JESUS, 2006, p. 9).

Em relação a sua natureza jurídica, a doutrina dominante sustenta a ausência de semelhança com qualquer prova nominada.

Não é confissão (strictu sensu), uma vez que esse meio de prova traduz-se numa declaração voluntária por quem seja suspeito ou acusado de um delito, a respeito de fato pessoal e próprio consistente na prática de fato criminoso. Pois bem, para a configuração da confissão, indispensável é que a afirmação incriminadora atinja o próprio confidente, e no caso da delação premiada dirige-se também contra um terceiro.

Também não é testemunho, afinal, um dos pressupostos para a validade de uma testemunha é ela ser pessoa estranha ao feito e eqüidistante das partes, o que inocorre na delação premiada, já que o delator é parte e tem interesse na solução da demanda, pois está na situação de beneficiário processual. Além do que, o delator está amparado pelo princípio nemo tenutur se detegere, ou seja, não presta o compromisso de falar a verdade, sob pena de incorrer no crime de falso testemunho.

Assim, a delação premiada é verdadeira prova anômala, por não se identificar com nenhuma outra prevista no ordenamento jurídico brasileiro. 
Não há como negar a sua qualidade de prova, porque assim como qualquer outra modalidade probatória, é instrumento através do qual o magistrado forma a sua convicção a respeito da ocorrência ou inocorrência dos fatos controvertidos no processo.

Reforça-se, deste modo, que a delação premiada é uma espécie de prova, apesar de não estar enumerada entre as demais previstas no Código de Processo Penal brasileiro, nos artigos 158 a 250. Daí ser denominada de prova inominada.

Reconhecida a sua natureza jurídica de prova, cumpre analisar o seu valor probatório, matéria esta bastante polêmica na doutrina e na jurisprudência brasileiras.

Alguns atribuem força incriminatória à delação, ao passo que outros a renegam, aceitando a valoração da delação como meio de prova apenas se ela estiver em sintonia com todo o conjunto probatório.

Enrico Altavilla é um dos que admite a força incriminadora da delação premiada, desde que ela esteja "vestida", isto é, seja compatível com o núcleo central acusatório. E acrescenta:

A acusação do co-réu não deve ser uma simples afirmação, antes precisa ser enquadrada numa narração completa. Efetivamente, não basta dizer que alguém tomou parte do crime, mas é necessário descrever a modalidade dessa participação, pois o pormenor pode revelar a veracidade ou a falsidade do que se narra. (apud ARANHA, 2006, p. 133).

Diversamente, Mittermayer, adepto da doutrina que relega a força condenatória da delação premiada, ventila que:

O depoimento do cúmplice apresenta também graves dificuldades. Tem-se visto criminosos que, desesperados por conhecerem que não podem escapar à pena, se esforçam em arrastar outros cidadãos para o abismo em que caem; outros denunciam cúmplices, aliás inocentes, só para afastar a suspeita dos que realmente tomaram parte no delito, ou para tornar o processo mais complicado, ou porque esperam obter tratamento menos gravosos, comprometendo pessoas em altas posições. (MITTERMAYER, 1996, p. 195).

Como se constata, a valoração da declaração do co-réu delator é uma das questões mais controvertidas do procedimento probatório da criminalidade organizada.

Segundo Eduardo Araujo da Silva: 
Tal controvérsia decorre de dois aspectos que devem ser considerados pelo juiz quando da análise desse meio de prova: (a) o acusado não presta o compromisso de falar a verdade em seu interrogatório; (b) está na situação de beneficiário processual e poderá figurar como beneficiário penal. A combinação desses fatores conduz à conclusão de que o co-réu pode colaborar falsamente com a Justiça, incriminando indevidamente os demais acusados em troca de benefícios previstos em lei. (manutenção do sistema de proteção, cumprimento de pena em regime especial, concessão de perdão judicial, diminuição de pena). (SILVA, 2003, p. 145).

A par desta realidade, a delação suscita certo cuidado ao ser coligida como prova de força condenatória. O mais sensato é admiti-la como elemento essencial para a formação do livre convencimento do juiz se analisada em conjunto com todos os demais meios de prova.

Basta agora classificar a delação premiada, que de acordo com a doutrina, pode ser preventiva ou repressiva.

A delação preventiva é aquela que ocorre na fase de investigação criminal, quando o co-réu, além de confessar sua participação no delito, evita que outros crimes venham a se consumar.

Já a delação repressiva perfaz-se naquela em que o delator colabora concretamente com as autoridades responsáveis pela persecução penal em suas atividades de agregar provas contra os demais co-autores, possibilitando a responsabilização penal destes.

\subsection{Introdução no Brasil e sua evolução legislativa}

No Brasil a origem da delação premiada remonta às Ordenações Filipinas, cuja parte que dispunha sobre matéria criminal (Livro V), vigorou de 1603 até a entrada em vigor do Código Criminal de 1830.

O germe da delação encontra-se, mais especificamente, nos Títulos VI e CXVI do Livro Quinto dessas Ordenações, nos quais havia previsão não só de mero perdão, mas também de autêntico prêmio ao indivíduo que apontasse o culpado.

Atualmente, não há uma única lei disciplinando as hipóteses de delação premiada. Ressalta-se, de plano, que há um emaranhado desregrado e assistemático de normas destinado ao tratamento do instituto, do qual decorrem diversos questionamentos que não poderão ser exauridos neste trabalho de contornos reduzidos - daí limitar-se a rápidas reflexões e apenas ao enfoque de alguns pontos selecionados. 
A Lei 8.072/1990, a chamada "Lei dos Crimes Hediondos", foi a que gizou os primeiros contornos da delação premiada no Brasil, posteriormente, inúmeras legislações abrigaram-na em seus corpos.

Esta Lei previu duas hipóteses de delação premiada, ambas como causa de diminuição de pena. A primeira delas estava contida na primitiva inserção de um parágrafo 4으 no artigo 159 do Código Penal que dispunha: "se o crime é cometido por quadrilha ou bando, o co-autor que denunciá-lo à autoridade, facilitando a libertação do seqüestrado, terá a sua pena reduzida de um a dois terços". Depois, a Lei 9.269/1996, modificou esse parágrafo, e nos dias atuais preceitua que: "se o crime é cometido em concurso, o concorrente que o denunciar à autoridade, facilitando a libertação do seqüestrado, terá a sua pena reduzida de um a dois terços".

Assim, com a nova redação dada ao parágrafo 4으 do artigo 159 do Código Penal, excluiu-se a exigência de que o delito de extorsão mediante seqüestro seja praticado por bando, bastando atualmente dois ou três agentes em concurso e que a "denúncia” (delação) provenha de um deles de maneira eficaz e suficiente para possibilitar a libertação da vítima.

A segunda hipótese de delação premiada na Lei dos Crimes Hediondos encontra-se no parágrafo único do seu artigo 8o: “o participante e o associado que denunciar à autoridade o bando ou a quadrilha, possibilitando seu desmantelamento, terá a pena reduzida de um a dois terços". Tal preceito disciplina uma causa especial de diminuição de pena, reclamando que algum integrante da quadrilha ou bando, assumindo sua responsabilidade penal, apresente informações à autoridade policial, judiciária ou a um representante do Ministério Público, de forma a proporcionar o seu desarranjo.

Depois, a Lei 9.034/1995 também tratou da delação premiada ao dispor em seu artigo 60: "nos crimes praticados em organizações criminosas, a pena será reduzida de um a dois terços quando a colaboração espontânea do agente levar ao esclarecimento de infrações penais e sua autoria".

A incidência desta Lei limita-se no plano dos "crimes praticados em organizações criminosas". Estas não se confundem com o delito de quadrilha ou bando, como se tentou demonstrar (item 1.3). Portanto, os efeitos da mitigação da pena restringem-se aos delitos perpetrados pela organização criminosa, não abrangendo os eventuais delitos de quadrilha ou bando. 
Decorrido algum tempo, a Lei Federal 9.080, promulgada em 19 de julho de 1995, inseriu a delação premiada na Lei 7.492/1986 (Lei dos Crimes contra o Sistema Financeiro e Nacional) e na Lei 8.137/1990 (Lei dos Crimes contra a Ordem Tributária, Econômica e contra as Relações de Consumo).

Desta forma, o instituto premial passou a ser previsto tanto na Lei 7.492/1986 como na Lei $8.137 / 1990$, pelos artigos 25 , parágrafo 2ㅇ e 16, parágrafo único, respectivamente, ambos com a seguinte redação:

Nos crimes previstos nesta Lei, cometidos em quadrilha ou co-autoria, o co-autor ou partícipe que através da confissão espontânea revela à autoridade policial ou judicial toda a trama delituosa terá a sua pena reduzida de um a dois terços.

Através deste tratamento dado à delação premiada nas Leis acima citadas, o ordenamento jurídico brasileiro, pela primeira vez (já que a Lei 9.080/1995 é anterior à alteração do parágrafo 4음 do artigo 159 do Código Penal) consentiu a redução da pena fora dos casos de quadrilha ou de organização criminosa, admitindo, pois, a aplicação do benefício ainda na situação de existir mera co-autoria.

Versou-se também na Lei 9.613/1998 sobre a delação premiada. Tal legislação, intitulada de "Lei de Lavagem de Capitais", aborda acerca da delação no parágrafo 5o do seu artigo 1:

\begin{abstract}
A pena será reduzida de um a dois terços e começará a ser cumprida em regime aberto, podendo o juiz deixar de aplicá-la ou substitui-la por pena restritiva de direitos, se o autor, co-autor ou partícipe colaborar espontaneamente com as autoridades, prestando esclarecimentos que conduzam à apuração das infrações penais e de sua autoria ou localização de bens, direitos ou valores objeto do crime.
\end{abstract}

De fato esse dispositivo inovou o tratamento até então dispensado à delação premial. Nele destaca-se um rol de vantagens ofertadas ao colaborador (delator), cuja pluralidade de opções era inexistente no ordenamento legal brasileiro.

Dentre elas, figuram a tradicional redução de penas, mas agora com o início obrigatório de seu cumprimento de pena em regime aberto, e duas novas previsões: a substituição de pena privativa de liberdade por restritivas de direitos e o perdão judicial.

A delação também está consagrada na Lei 9.807, de 13 de julho de 1999 (Lei de Proteção às Vítimas e às Testemunhas). 
Nota-se que a Lei 9.807/1999 seguiu a tendência ditada pela "Lei de Lavagem de Capitais" ao permitir não só uma causa obrigatória de redução de pena, mas, também, a aplicação de perdão judicial aos réus colaboradores.

Ainda no que tange à essa Lei, indispensável é realçar que enquanto, todas as leis anteriormente mencionadas são casuísticas, ou seja, fazem referência à delação em crimes específicos ou quando houver o envolvimento de organização criminosa, a "Lei de Proteção às Vítimas e às Testemunhas" é mais ampla, vez que admite a sua incidência em relação a qualquer tipo de infração penal, inclusive nos crimes ora aludidos, pois nela não há qualquer restrição no que diz respeito às hipóteses de cabimento.

Cabe também tecer sucintos comentários à previsão do direito premial na Lei $10.409 / 2002$.

Ainda que essa Lei tenha sido revogada pela atual Lei 11.343, de 23 de agosto de 2006, sua abordagem é interessante, visto que, com ela a delação premiada havia ganhado uma nova roupagem. Ocorre que, a Lei 10.409/2002, além de ter estatuido a possibilidade de diminuição de pena e perdão judicial acrescentou uma inovação em termos de vantagens concedidas em razão da delação premiada, ainda mais radical que esse último. Cuidava-se da hipótese contida no parágrafo 2 ㅇ do seu artigo 32 , assim descrita:

O sobrestamento do processo ou a redução da pena podem ainda decorrer de acordo entre o Ministério Público e o indiciado que, espontaneamente, revelar a existência de organização criminosa, permitindo a prisão de um ou mais dos seus integrantes, ou a apreensão do produto, da substância ou da droga ilícita, ou que, de qualquer modo, justificado no acordo, contribuir para o interesse da justiça.

Por fim, mais recentemente, vigora a Lei $11.343 / 2006$. Pela nova regra insculpida no artigo 41 desta Lei, não se possibilita mais, em face de delação premiada, o sobrestamento das investigações, prevendo apenas a permissão para a diminuição da pena dentro do patamar que pode variar entre um e dois terços da reprimenda imposta, não sendo mais possível nem mesmo o perdão judicial.

Visíveis são as variações no regramento da delação premiada nas inúmeras leis que a disciplinam. Em razão desta multiplicidade de leis regulamentando o instituto em comento, a doutrina preponderante entende que a Lei 9.807/1999 passou a ser o diploma a regulamentar a delação premiada no Brasil, por ser mais benéfica do que as leis anteriores a 
ela. Alguns doutrinadores, como Alberto Silva Franco, a vêem como uma lei revogadora das precedentes. (FRANCO, 1992, p. 354). Contudo, o melhor posicionamento é o que concebe tal Lei como sendo de aplicação genérica, sendo as anteriores de incidência subsidiária, não estando assim revogadas, mormente quando seus requisitos são menos rigorosos do que os encampados na Lei estudada.

\subsection{Requisitos para a admissão da delação premiada}

Como se viu (item 3.2), no Brasil não há padronização no tratamento do direito premial, o qual é objeto de considerações espalhadas em peças nada conexas como a Lei dos Crimes Hediondos, a Lei de Repressão ao Crime Organizado, a Lei contra o Sistema Financeiro e Nacional, a Lei dos Crimes contra a Ordem Tributária, Econômica e contra as Relações de Consumo, a Lei de Lavagem de Capitais e a Lei de Proteção às Vítimas e às Testemunhas.

Diante desta realidade, para se fixar os requisitos para a admissão da delação premiada, dever-se-á observar as normas contidas em todas as leis que a invocam, devendo o hermeneuta se valer de uma interpretação sistêmica acerca das mesmas.

Os requisitos que serão aqui analisados são os da Lei 9.807/1999, em razão da aplicação da delação premiada dever centrar-se nela, dado o seu caráter genérico e mais benéfico em relação às demais legislações. Contudo, as peculiaridades de cada lei que dispõe sobre o instituto deverão ser respeitadas.

Analisando a Lei de Proteção às Vítimas e às Testemunhas apreende-se que, tanto para a concessão do perdão judicial (artigo 13) como para a diminuição da pena (artigo 14), exige-se a observância dos seguintes requisitos: voluntariedade da colaboração com o processo criminal ou investigação; resultado que atinja a identificação dos demais coautores ou partícipes, ou a localização da vítima ou a recuperação total ou parcial do produto do crime.

No que se refere à voluntariedade, a Lei preconiza ser desnecessária a espontaneidade no ato da delação.

O legislador, intencionalmente, utilizou a expressão "voluntariamente", ao invés de "espontaneamente". 
A diferença entre tais termos é fundamental. No ato espontâneo a iniciativa de praticá-lo emana do próprio delator, é um ato que nasce unicamente da vontade do agente sem a interferência de terceiros. Já no ato voluntário não se exige que a idéia de realizá-lo tenha partido do próprio agente, basta que ele se efetive sem coação, sendo irrelevante a causa que o motivou.

As declarações do investigado ou réu terão que ostentar importância em relação ao fato objeto da investigação ou do processo, resultando das mesmas a possibilidade, por exemplo: de identificação dos demais co-autores ou partícipes do crime; a localização da vítima; a recuperação total ou parcial do produto do crime.

Em vista disso, deve-se buscar nas declarações do delator informações que de qualquer forma venham a contribuir com o interesse da Justiça, devendo ser vedada qualquer iniciativa de "acordo" que não vislumbre sinais de relevância em relação ao fato como por exemplo, quando os dados prestados pelo co-réu já foram alcançados através de outros meios de obtenção de prova.

Além dos requisitos comuns pleiteados pelos artigos 13 e 14 da Lei 9.807/1999, também existem outros que se apresentam como um "plus" para a concessão do perdão judicial. Esse benefício por ser acentuadamente mais favorável reclama além dos requisitos já analisados as seguintes exigências: primariedade do acusado, efetividade da colaboração, circunstâncias pessoais e do fato criminoso inteiramente favoráveis e a localização da vítima com a sua integridade física preservada.

A primariedade trata-se de um requisito não presente em outras normas relativas à delação premiada e que reduz, de certo modo, o seu alcance. Por primário, deve-se entender, por exclusão, o não reincidente (aquele que já tendo sido condenado anteriormente por crime, comete outro delito no período de cinco anos, computados a partir da extinção da pena anterior, de acordo com o artigo 64, I do Código Penal).

A efetividade, por sua vez, correlaciona-se com a magnitude do resultado, sendo que o perdão judicial apenas poderá ser decretado em casos que o resultado conseguido pela delação seja suficientemente relevante. Na visão de Eduardo Araujo da Silva, "trata-se de outro requisito sensível, porquanto nem sempre é possível avaliar com precisão em que proporções o colaborador está auxiliando as autoridades". (SILVA, 2003, p. 83). 
Dentro da concepção de que a Justiça Penal é uma Justiça dos casos concretos, o legislador para a concessão do perdão judicial também levou também em conta a natureza, as circunstâncias, a gravidade e a repercussão social do fato criminoso. Todas essas questões estão diretamente ligadas à atividade estatal de avaliação da adequação, oportunidade e conveniência de se aplicar o perdão judicial mediante a apreciação da culpa do agente e da finalidade da resposta jurídica da qual se vai abdicar. Aí se assenta a coerência legislativa de permitir ao julgador a aplicação ou não do instituto extintivo da punibilidade.

A última distinção entre as exigências dos artigos 13 e 14 da Lei de Proteção às Vítimas e às Testemunhas é a de que, para a admissibilidade do perdão judicial, não é suficiente o encontro da vítima com vida, exige-se também que a sua integridade física tenha sido preservada.

Em face de todos esses requisitos, há que se concluir que, apesar da nebulosidade da Lei a respeito da cumulatividade ou alternatividade dos requisitos enunciados em seus artigos 13 e 14, deve-se acolher a tese da alternatividade, isto é, não é necessário sempre a identificação dos demais autores, mais a recuperação do produto do crime e mais a libertação da vítima. Fossem cumulativos os requisitos, a Lei perderia o seu significado e limitaria a sua aplicação ao crime de extorsão mediante seqüestro, por ser o único delito que permite a satisfação de todos esses requisitos.

Além dos requisitos alinhavados pela Lei para a admissão da delação premiada e a conseqüente diminuição de pena ou perdão judicial, deve-se ter em mente que a delação só deveria ser aplicada em caráter excepcional, no caso em que a extrema necessidade a demandasse perante a falta de outras provas aptas à apuração do crime e a posterior punição de seus autores e partícipes.

A delação não deveria ser estendida a todas as matizes de criminalidade, como o foi pela Lei 9.807/1999. Tal qual afirma Alberto Silva Franco, "só teria cabimento em situações muito especiais e em nenhum outro delito a mais." (FRANCO, 1992, p. 316).

\subsection{Conseqüências possíveis advindas da aplicação da delação premiada}

Cabe agora a análise das conseqüências que poderão sobrevir da aplicação da delação premiada, tanto em relação ao réu delator, quanto à sociedade. 


\subsubsection{Em relação ao relator}

Ao réu delator cabem duas benesses, quais sejam, o perdão judicial ou a diminuição de sua pena.

Preenchidos os requisitos do artigo 13 da Lei 9.807/1999, o delator fará jus ao perdão judicial.

Para a concessão deste benefício, repise-se, o réu deverá ser primário e ter colaborado efetiva e voluntariamente com a investigação e o processo criminal, além de sua colaboração ter resultado na identificação dos demais co-autores ou partícipes da conduta criminosa, na localização da vítima com a sua integridade física preservada ou na recuperação total ou parcial do produto do crime.

Já a redução da pena, que é o "prêmio" previsto no artigo 14 da Lei de Proteção às Vítimas e às Testemunhas, é plausível se o indiciado ou acusado colaborar voluntariamente com a investigação policial e o processo criminal na identificação dos demais co-autores ou partícipes do crime, na localização da vítima com vida e na recuperação total ou parcial do produto do crime. Ou seja, a redução da pena estará presente no caso de o réu não preencher todos os requisitos do artigo 13 da Lei 9.807/1999 que lhe garantiria a concessão do perdão judicial.

Em linhas gerais, pode-se afirmar que a concessão de tais benesses dependerá do exame do caso concreto, cabendo a decisão da aplicação de um benefício ou outro, ou de nenhum deles, ao juiz competente, por ocasião da sentença, ao reconhecer que a colaboração foi eficiente ou não. O perdão judicial, bem como a diminuição da pena são atribuições do magistrado, sendo que o Ministério Público e o órgão policial somente podem requerer ao juiz a aplicação do benefício, como estipula o artigo 13 da Lei 9.807/1999.

Contudo, tanto a Defesa como o Ministério Público poderão se insurgir contra a decisão do magistrado que não acolher o pedido de concessão dos benefícios da delação premiada quando esta foi concretamente efetivada. Assim, tal decisão deverá ser rebatida através de recurso de apelação. Isso se dá em virtude desses benefícios serem considerados, ao menos pela maior parte da doutrina, como direito subjetivo do acusado delator, o que significa dizer que, se houver o atendimento aos requisitos do texto legal, não há como afastar a concessão da benesse cabível, pois ela não se subjuga ao arbítrio ou capricho do juiz. 
Outra conseqüência para o delator advinda da delação premiada é a de que, seja na situação do artigo 13 ou na do artigo 14, o artigo 15 da mesma lei 9.807/1999, determina uma regra geral de aplicar em benefício do delator, na prisão ou fora dela, medidas especiais de segurança e proteção à sua integridade física.

Nesse prisma, sempre que existir ameaça ou coação, o delator terá direito à proteção de sua integridade física.

Apesar do artigo 15 não pontuar o que sejam as medidas especiais de segurança e proteção, conclui-se que seriam aquelas estabelecidas no artigo 70 da mesma lei, no que for compatível, ou melhor, ao delator devem ser oferecidas as mesmas condições que à testemunha ou à vítima que necessita de segurança.

Deste modo, além da redução da pena ou do perdão judicial, o delator que não estiver custodiado poderá ser inscrito em programa de assistência instituído em cada Estado (ou Federal, se for o caso), através do qual lhe serão propiciadas as medidas de proteção que se mostrem adequadas e que estejam previstas no artigo 7으 da lei 9.807/1999.

Contudo, para o delator condenado que esteja cumprindo pena ou quando esteja sob prisão cautelar (artigo $2^{\circ}$, parágrafo $2^{\circ}$ ) veda-se a sua inserção nesse programa. Nessa hipótese, embora o dispositivo determine a exclusão do programa, adverte que ela não provocará prejuízos às medidas de preservação da integridade física do delator.

Em poucas palavras, se estiver solto, o delator poderá ser inserido no programa de assistência, recebendo todas as medidas ofertadas às vítimas e às testemunhas. Mas se estiver preso, não poderá se enquadrar nesse programa, restando-lhe a garantia das providências que resguardem a sua integridade física e moral, uma vez que, o dever constitucional dos órgãos de segurança pública de tutelar a incolumidade física das pessoas subsiste (artigo 144 da Constituição Federal $^{3}$ ), mesmo que o delator não se amolde às hipóteses de inclusão no programa de proteção.

\footnotetext{
3 Tal artigo preceitua que:

“A segurança pública, dever do Estado, direito e responsabilidade de todos, é exercida para a preservação da ordem pública e da incolumidade das pessoas e do patrimônio, através dos seguintes órgãos:

I- polícia federal;

II- polícia rodoviária federal;

III- polícia ferroviária federal;

IV- policiais civis;

$\mathrm{V}$ - policiais militares e corpos de bombeiros militares.

(...)
} 


\subsubsection{Em relação à sociedade}

Data maxima venia, em que pese o instituto da delação premiada ser repelido por parte da doutrina, ele traz inúmeras vantagens à sociedade por ser uma forma eficiente de combate à criminalidade organizada.

O principal argumento dos críticos é a falta de fundamento ético na delação premiada. Para Damásio E. de Jesus, a delação premiada "não é pedagógica, porque ensina que trair traz benefícios". (JESUS, 1994, p. 5).

Entretanto, tal crítica é muito questionável, afinal, a denúncia de um crime deve ser estimulada como obrigação do sujeito que, ao delatar a ação criminosa e levar à punição dos criminosos, estará colaborando para o bem comum.

Na realidade, há que sopesar a suposta ética do mundo do crime com o verdadeiro propósito do direito premial, que não é outro senão coibir a desastrosa criminalidade.

Os valores morais devem ser argüidos em defesa da sociedade e não para garantir a impunidade de criminosos que inclusive são capazes de matar seus comparsas - "queima de arquivos" - para impedirem que eles entreguem a organização criminosa às autoridades. Como reclamar pela ética na aplicação da delação premiada se na realidade ela inexiste no crime, que em si mesmo é avesso aos valores sociais e morais impostos para a sobrevivência pacífica entre os seres humanos, uma vez que rompe com as normas vigentes protetoras dos bens jurídicos tutelados pelo Estado.

O Direito Penal embebe-se de eticidade no momento em que cumpre a sua missão de pacificação social ao alcançar o alto escalão de criminosos que raramente seriam responsabilizados não fosse a delação premiada.

Com a delação a sociedade é beneficiada e muito, porque com a sua utilização permite-se a aplicação do Direito Penal em sua real dimensão, pois "dá à persecução penal um concreto instrumento para que busque a redução da impunidade no país e efetivo combate à criminalidade organizada". (MONTE, 2001, p. 237).

Sendo assim, pode-se afirmar que a delação premiada deve prevalecer em relação a qualquer desarrazoada crítica que prime pela suposta ausência de ética em sua aplicação.

O Estado Democrático de Direito pátrio é, na sua essência, um Estado Social, que se sedimenta no objetivo de realizar os direitos e valores humanos. 
A função síntese do Estado Social é promover o bem comum (artigo 193 da Constituição Federal ${ }^{4}$ ), e para tanto, o auxílio da delação premiada é de enorme valia, visto que ela arregimenta provas que seguramente não seriam obtidas por outros meios de investigação e mina a arquitetura associativa dos grupos criminosos.

A delação premiada tem o poder de minimizar a ignominiosa impunidade, já que é capaz de atingir criminosos que provavelmente escapariam à punição da lei penal por se acobertarem no manto da "lei do silêncio" das organizações criminosas e geralmente serem detentores de elevado poder aquisitivo. E não é só. Por tudo o que foi tratado, insta-se que a delação fortifica o mister do Direito Penal de possibilitar o jus puniendi do Estado toda vez que os bens jurídicos erigidos como mais importantes forem lesados ou ameaçados de lesão. A punição ocorre deveras. Se de um lado se concede um "prêmio" ao delator (perdão judicial ou redução da pena), por outro se desvenda os demais agentes criminosos cominando a eles as penas que lhes são devidas.

Convinhável que ela seja usada como ferramenta de promoção da segurança e da justiça, direitos estes que, de acordo com o preâmbulo da Lei Maior ${ }^{5}$, devem ser assegurados pelo Estado de Direito Democrático.

\section{Conclusão}

À guisa de conclusão, fica nítido, portanto, que as particularidades apresentadas pelas organizações criminosas nos dias atuais exigiram uma reestruturação da dogmática penal com a criação de estratégias diferenciadas para a obtenção da prova, entre elas, a delação premiada, na busca da eficiência penal.

Ao que tudo indica, a delação premiada é uma forma aconselhável de obtenção de provas que, se bem empregada, perfaz-se num excelente instrumento de efetivo combate à criminalidade organizada.

4 O aludido preceito dita que:

"A ordem social tem como base o primado do trabalho, e como objetivo o bem-estar e a justiça sociais". (grifo nosso).

5 O preâmbulo da Carta Constitucional de 1988 anuncia que:

"Nós, representantes do povo brasileiro, reunidos em Assembléia Nacional Constituinte para instituir um Estado Democrático, destinado a assegurar o exercício dos direitos sociais e individuais, a liberdade, a segurança, o bem-estar, o desenvolvimento, a igualdade e a justiça como valores supremos de uma sociedade fraterna, pluralista e sem preconceitos, fundada na harmonia social e comprometida, na ordem interna e internacional, com a solução pacífica das controvérsias, promulgamos, sob a proteção de Deus, a seguinte CONSTITUIÇÃO DA REPÚBLICA FEDERATIVA DO BRASIL." (grifo nosso). 
Outrossim, espera-se por meio deste trabalho ter contribuído com o desenvolvimento da matéria, semeando um terreno pouco explorado pelas doutrinas, para assim suscitar o debate, sempre com o objetivo construtivo de aperfeiçoar o tratamento do assunto.

\section{Referências}

ARANHA, Adalberto José Q. T. de Camargo. Da prova no processo penal. 7 ed., São Paulo: Saraiva, 2006.

BATISTA, Nilo. Introdução crítica ao direito penal brasileiro. 8 ed. Rio de Janeiro: Revan, 2002.

CAVALCANTI, Eduardo Medeiros. Crime e sociedade complexa: uma abordagem interdisciplinar sobre o processo de criminalização. 1 ed. Campinas: LZN, 2005.

CERQUEIRA, Thales Tácito Pontes de Pádua. Delação Premiada. Revista Jurídica Consulex, v. 9, n. 208, 15 set. 2005.

COSTA, Renata Almeida da. A sociedade complexa e o crime organizado: a contemporaneidade e o risco nas organizações criminosas. Rio de Janeiro: Lumen Juris, 2004.

FERREIRA, Aurélio Buarque de Holanda. Novo Aurélio Século XXI: Dicionário da Língua Portuguesa. 3 ed. Rio de Janeiro: Nova Fronteira, 1999.

FRANCO, Alberto Silva. Crimes hediondos. 2 ed. São Paulo: Revista dos Tribunais, 1992.

GOMES, Luiz Flávio; CERVINI, Raúl. Crime Organizado: enfoque criminológico, jurídico (Lei 9.034/95) e político-criminal. 2 ed. São Paulo: Revista dos Tribunais, 1997.

HASSEMER, Winfried. Segurança pública no estado de direito. Tradução de Carlos Eduardo Vasconcelos. Revista Brasileira de Ciências Criminais, São Paulo, n. 5, jan./mar. 1994.

JESUS, Damásio Evangelista de. Direito Penal. São Paulo: Saraiva, 1998.

. Estágio atual da delação premiada no direito penal brasileiro. Revista Bonjuris, v. 18, n. 506, jan. 2006. 
. O fracasso da delação premiada. São Paulo: Boletim do Instituto Brasileiro de Ciências Criminais, v. 2, n. 21, set. 1994.

LAVORENTI, Wilson; SILVA, José Geraldo da. Crime organizado na atualidade. Campinas: Bookseller, 2000.

LIPINSKI, Antonio Carlos. Crime Organizado \& Prova Penal. Curitiba: Juruá, 2006.

LUISI, Luiz. Os princípios constitucionais penais. Porto Alegre: Fabris, 1991.

MAIA, Rodolfo Tigre. O Estado desorganizado contra o crime organizado: anotações à Lei Federal no 9.034/95 (Organizações Criminosas). Rio de Janeiro: Lumem Juris, 1997.

MENDRONI, Marcelo Batlouni. Crime Organizado: aspectos gerais e mecanismos legais. São Paulo: Juarez de Oliveira, 2002.

MITTERMAYER, C. J. A. Tratado da prova em matéria criminal. Tradução de Hebert Wüntzel Heinrich. 3 ed. Campinas: Bookseller, 1996.

MONTE, Vanise Röhrig. A necessária interpretação do instituto da delação premiada, previsto na Lei 9.807/99, à luz dos princípios constitucionais. Revista Ajuris, Porto Alegre, v. 16, n. 82, 2001.

NUCCl, Guilherme de Souza. Código de Processo Penal Comentado. 5 ed., São Paulo: Revista dos Tribunais, 2006.

2006.

. Leis penais e processuais penais comentadas. 1 ed. São Paulo: Revista dos Tribunais, . O valor da confissão como meio de prova. São Paulo: Revista dos Tribunais, 1997.

ROBINSON, Jeffrey. A globalização do crime. Rio de Janeiro: Ediouro, 2001.

SILVA, Eduardo Araujo da. Crime organizado: procedimento probatório. São Paulo: Atlas, 2003.

SIQUEIRA FILHO, Élio Wanderley de. Repressão ao crime organizado: inovações da Lei 9.034/95. 2 ed. Curitiba: Juruá, 2003. 
